\title{
A Study of Changing Key Performance Indicators in Banking Sector
}

\author{
Afroze Nazneen ${ }^{1}$, Shikha Goyal ${ }^{2}$, Pretty Bhalla ${ }^{2}$ \& Vikram Jeet ${ }^{1}$ \\ ${ }^{1}$ College of Business, University of Jeddah, Jeddah, KSA \\ ${ }^{2}$ Lovely Professional University, Phagwara \\ Correspondence: Dr. Afroze Nazneen, College of Business, University of Jeddah, Jeddah, KSA.
}

Received: May 19, 2019

Accepted: August 16, $2019 \quad$ Online Published: September 26, 2019

doi:10.5430/rwe.v10n3p56

URL: https://doi.org/10.5430/rwe.v10n3p56

\begin{abstract}
The Indian banking system has taken huge strides from being into traditional banking system to nationalization to privatization and finally into multinationals. The success dimension of Indian banks doesn't only stand on financial indicators but it draws a thrust from, organizational culture, and customer relationships go a long way toward dictating future financial performance.The great transformation has been witnessed in the performance measurement system wherein the traditional performance appraisal system was taken over by multifaceted performance management system with feedback and continuous monitoring as inseparable part of it.In this paper, the researcher has proposed a model for measurement of performance in banking sector. And also the key variables have been found which are valuable in performance analysis.
\end{abstract}

Keywords: appraisal, organizational culture, performance, privatization, transformation

\section{Introduction}

Term "Performance Measurement" has till date achieved considerable limelight and new dimensions. The golden adages as "what gets measured gets done" and "you get what you measure" suggest that incorporation of required performance measurement tool would lead to a directed approach in achieving desired strategies and objectives (Lynch and Cross, 1991).It is absolutely essential to develop a performance evaluation system that encompasses all aspects of an organization, if the organization aims at the long term survival, growth and development. Such a system could be capable of bringing out the strengths and weaknesses of the organization for the purpose of further improvement. With the advances in computational tools, various performance measurement and evaluation systems have evolved over a period of time from single-aspect systems to more comprehensive systems covering all aspects of an organization.

In the business world the only thing that really matters is organization's performance. The introduction of performance management of commercial banks is of crucial significance owing to the openness of India to the world and investors abroad after 1991 liberalization, privatization and globalization. The holistic performance measures adopted by Banking sector as Balanced Score Card(BSC) measuring financial andnon financial aspects has proved to be a powerful weapon for investors.

\subsection{Performance Aspect of Banking Sector}

Indian banking sector has emerged as one of the strongest drivers for India's economic growth. The Indian banking system is among the healthier performers in the world, when compared with top three banks in total assets and in terms of return on assets.

A diverse range of studies have been conducted by the researchers for measuring the performance of the banks, which present different perspective with regarding the performance of the banks in different countries. Traditional systems of performance evaluation of banks mostly use the factors like ROA and ROI for measuring the financial performance of the banks. However, nowadays intellectuals and managers of organization find that traditional systems of performance evaluation have been typically based on financial views which are incomplete in evaluating overall performance of the organization and representing an effective feedback. Excessive financial measurements may increase organization's short term profit, but bring about losing competitive situation and threatens long-term profit.

Customer's Perspective, Internal Business Process Perspective, Learning and Growth Perspective and Corporate Social Responsibility are the Non financial perspectives which are vital for any bank to grow and succeed. Customer satisfaction is the key to the profitability of retail banking, which is having a long term financial impact on the business 
of the banks. Performance of the banks depends upon the efficiency and level of satisfaction of its human resources. High level of human capital efficiency and employee satisfaction leads to the high performance of the banks. It has also been found by the researchers that the banks which adhere to be socially responsible in their routine activities, outperform in their financial performance. There stands a positive relationship between the CSR and the financial performance of the banks both in long and short term perspective. Thus there are two main aspects from which one can measure the overall performance of the banks namely, financial aspects and human aspects.

The following conceptual model explains the performance and its dimensions.

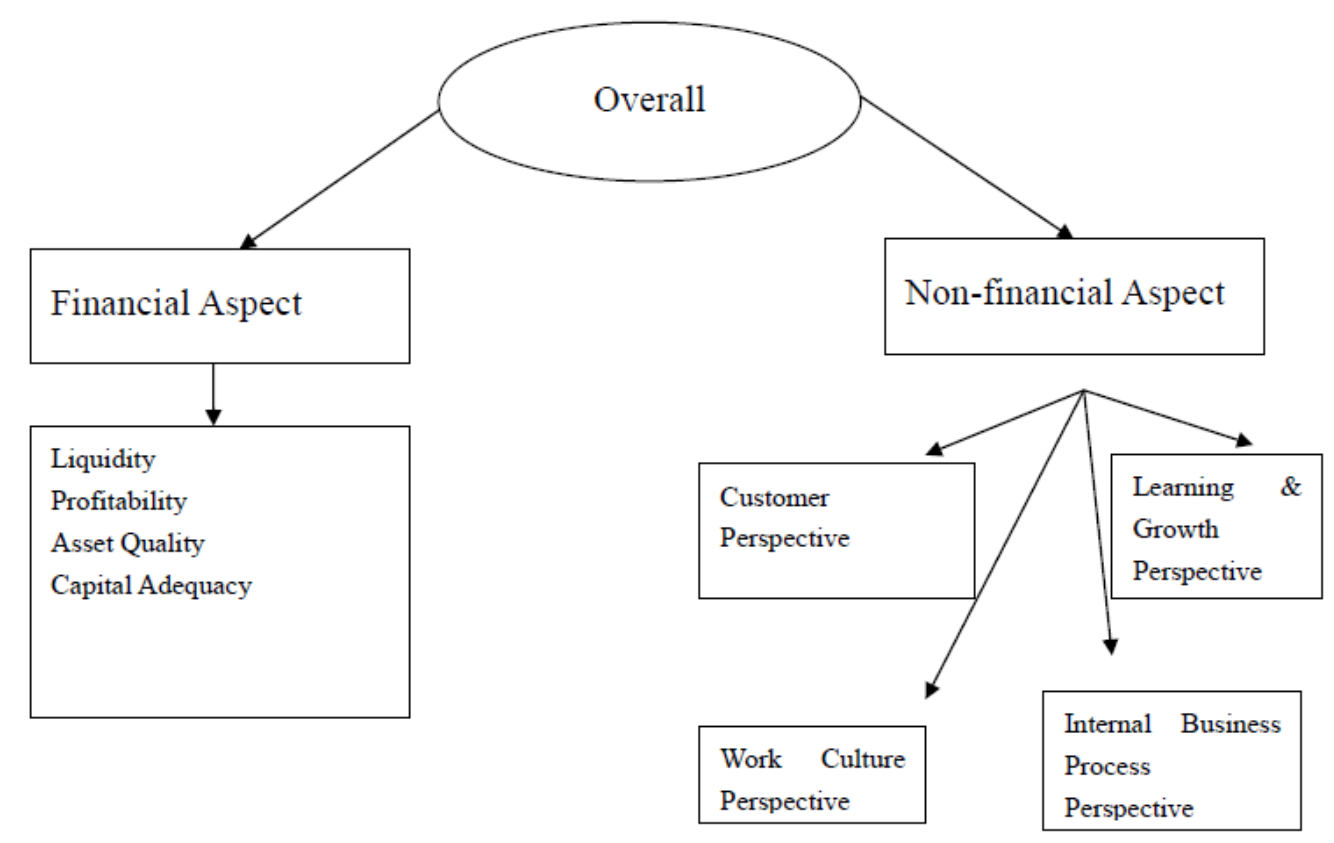

Figure 1. Conceptual model

\section{Review of Literature}

Anyanwokoro (1999) defined electronic banking as "the application of computer technology to banking especially the payment (deposit transfer) aspects of banking. He also defined e-banking as a system of banking with an electronic communication network which permits on-line processing of the same day credit and debit transfers of funds between member institutions of a clearing system. In short, we can say that E- Banking is defined as using electronic devices like internet, wireless connection networks, ATM, phone and cell phone in banking services. These services were parts of providing currency for economic system of the country".

Garrett Walker, J. Randall MacDonald (2001): This study has given the solution of Questions arisen by GTE's HR managers in order to effectively manage the value created by investments in employees because the primary source of competitive advantage is the ability to effectively manage the employee talent. So, researchers found the Human Resource challenges and strategy in order to build the communication and reinforcement in the linkage between HR actions and business results. And the solution to all the questions is to track financial results while monitoring progress in developing human capital and acquiring talent and capabilities for business success.

B. Janki (2002) analyzed that how technology is affecting the employees' productivity.Ther is no doubt, in India particularly public sector banks will need to use technology to improve operating efficiency and customer services. "The focus on technology will increase like never before to add value to customer services, develop new products, strengthen risk management etc". The study concludes that technology is the only tool to achieve their goals.

Simpson (2002) suggests that E-banking is driven largely by the prospects of operating costs minimization and operating revenues maximization. To know the profitability through using e- channels

Kai Kristensen, Anders H. Westlund (2004): This study has demonstrated a relationship between employee satisfaction and customer satisfaction. And also demonstrated a clear relationship between customer 
loyalty/satisfaction and the actual financial performance in the company. This relationship contains an expected time lag, which calls for careful planning when using the balanced scorecard for managerial purposes.

Stan Davis, Tom Albright (2004): In this quasi-experimental study, they had investigated that "bank branches implementing the Balanced Scorecard (BSC) outperformed bank branches within the same banking organization on key financial measures. They had evidently proved that financial performance for branches implementing the BSC are superior when compared to performance of non-BSC implementing branches".

Jham, ViliI, Khan, Kaleem Mohd (2008) conducted study on "Determinants of Performance in Retail Banking: Perspectives of Customer Satisfaction and Relationship Marketing"This study explores the satisfaction variables within thebanking industry. The key findings of an empirical research are based on the datacollected from 555 customers. Systematic methodology, including design andvalidation of questionnaire, factor analysis and regression analysis were utilized toenhance reliability of the findings. The study reinforces that customer satisfaction islinked with performance of the banks. The authors demonstrate how adaptation ofsatisfaction variables can lead to better performance.

Alex (2014) examined the impact of e-banking on customer services and profitability of banks. The study found that e-banking has impacted positively on customer service and profitability of banks, though the study identified a number of challenges, it thus recommended among others that there should be 24/7 monitoring of ATMs so that any failure is addressed as soon as possible to guarantee customer retention.

Adewoye (2013) equally examined the impact of mobile banking on service delivery in the banks. The study employed primary data sourced through questionnaires, which were administered to staff and customers of some selected banks in the country. The results show that mobile banking improves banks service delivery in a form of transactional convenience, saving time and so on. To this end, the study recommended that banks management should create awareness to inform the public about the benefits delivered on the e-banking service products.

Aspal et al (2019) examined the Significance of Bank Specific and Macroeconomic Determinants on Performance of Indian Private Sector Banks. Using multiple regression technique the analysis of sample data for the time period 2008-2014 revealed that except capital adequacy ratio variable all other bank specific variables (Asset Quality, Management Efficiency, Earning Quality and Liquidity) and macroeconomic variable gross domestic product had significantly influenced the financial performance of sample banks in India. The implications of the study revealed that inspite of optimum capital adequacy ratio maintained by private sector banks, the other variables related with management and governance of banks had significant effect on the financial performance of the banks.

\section{Perspectives for Measuring Performance}

\subsection{The Financial Perspective}

Kaplan and Norton do not ignore the conventional need for fiscal data. Judicious and precise funding data will always be a precedence, and necessary steps would be taken by managers to provide it. In fact, often there is more than enough handling and processing of financial data. Centralized and automated processing can be implemented for corporate database. But the issue is that the regular importance on financials leads to the "unbalanced".

Management currents trends lay strong importance of customer focus and customer satisfaction in any business. As rightly said Customer is a king, if customers are not satisfied, they will ultimately find other suppliers that will meet their needs. Even though the current financial picture may look good butPoor performance from this perspective would lead to future decline.

In creating metrics for satisfaction, customers should be categorized in terms of customers type and the kinds of work for which the Bank is providing a product or service to those customer groups.

Depending on the situation (strategy and key success factors) the company may require indicators reflecting product share in total purchase volumes of customers, number of contacts with customers, number of employees who regular contact customers, etc.

\subsection{The Business Process Perspective}

This perspective refers to internal business processes. Metrics based on this perspective allow managers to know how well the Bank is running, and whether its products and services conform to customer requirements (the mission). These metrics have to be carefully designed by those who know these processes most intimately; with Bank's unique missions these are not something that can be developed by outside consultants.

\subsection{The Learning and Growth Perspective}

This perspective includes employee training and corporate cultural attitudes related to both individual and corporate self-improvement. In a knowledge-worker organization such as a Bank, people -- the only repository of knowledge -- 
are the main resource. In the current climate of rapid technological change, it is becoming necessary for knowledge workers to be in a continuous learning mode. Banks sometimes find themselves unable to identify, recruit, and hire new qualified knowledge workers, and at the same time there is sometimes a lack of training of existing employees. This is a leading indicator of 'brain drain' that must be reversed. Metrics can be put into place to guide managers in focusing training funds where they can help the most. In any case, learning and growth constitute the essential foundation for success of any knowledge-worker organization.

\subsection{Work Culture Perspective}

In addition to all four perspectives, a cohesive culture determines the appropriateness of a firm's activities that can contribute to its performance. In fact, organizational culture is not just an important factor of an organization; it is the central driver of superior business performance (Gallagher \& Brown, 2007). In the article entitled "A Strong Market Culture Drives Organizational Performance and Success", Gallagher and Brown (2007) stated that an organization's work culture influences everything which an organization does. It is the core of what the company is really like, how it operates, what it focuses on, and how it treats customers, employees, and shareholders. Research on the link between organizational culture and performance has increased substantially during the past decade (Lim, 1995).

\section{Measurement Model Exhibiting Seven Constructs of Balanced Scorecard Performance Appraisal System}

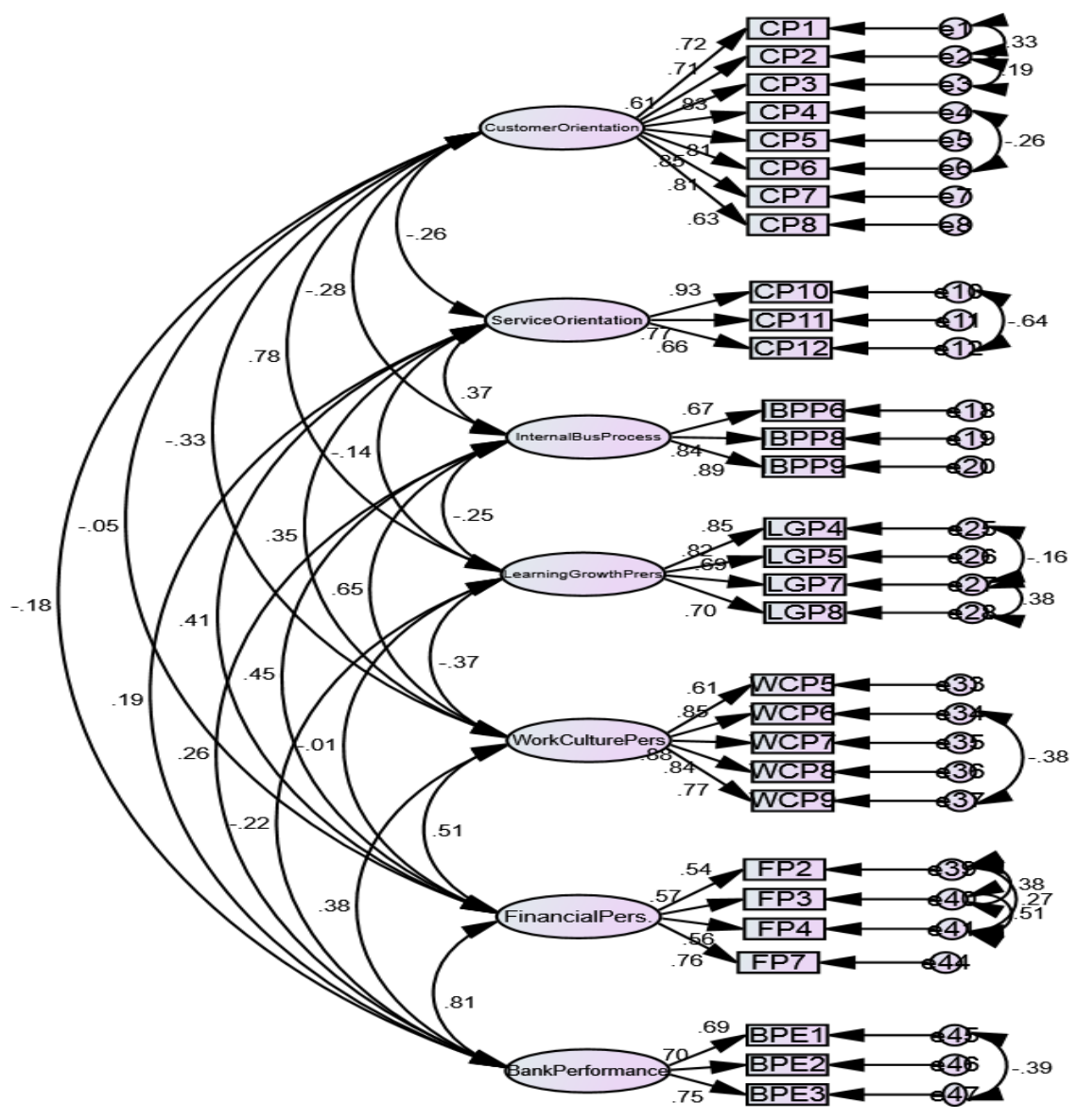

Figure 2. Measurement model exhibiting seven constructs of balanced scorecard performance appraisal system

This model is reflective in nature in which a construct is expected to be measured using multiple statements. The arrows move from the construct to the observed variable. The strength of relationship is termed as factor loadings $(\lambda)$. The value of factor loadings would lie between 0 and 1 . Higher the value, stronger the relationship. 


\section{Standardized Regression Weights or Factor Loadings $(\lambda)$}

Table 1 exhibits the standardized regression weights or factor loadings. As it can be seen that all of the factor loadings are greater than 0.5 . Most of the factor loading were greater than 0.6 suggesting significant factor loadings.

Table 1. Standardized regression weights or factor loadings $(\lambda)$

\begin{tabular}{|c|c|c|c|}
\hline & & & Estimate \\
\hline $\begin{array}{l}\text { CP1 Product designing as per requirement of } \\
\text { customers on a regular basis }\end{array}$ & $<---$ & CustomerOrientation & .725 \\
\hline CP2 Number of redressal of customer complaints. & $<---$ & CustomerOrientation & .706 \\
\hline CP3 Handling queries satisfactorily. & $<---$ & CustomerOrientation & .606 \\
\hline CP4 Banking network is accessible in all regions. & $<---$ & CustomerOrientation & .832 \\
\hline CP5 Proactive communication. & $<---$ & CustomerOrientation & .812 \\
\hline CP6 Responsiveness(prompt services to customers) & <--- & CustomerOrientation & .854 \\
\hline CP7 Mobile Banking services. & $<---$ & CustomerOrientation & .812 \\
\hline CP8 Internet banking services. & $<---$ & CustomerOrientation & .627 \\
\hline CP10 Senior citizens properly attended. & $<---$ & ServiceOrientation & .929 \\
\hline CP11 May I help you counter available? & $<---$ & ServiceOrientation & .766 \\
\hline CP12 Prior notice about changes in charges. & <--- & ServiceOrientation & .658 \\
\hline IBPP6 Multifunctional ATMs & $<--$ & InternalBusProcess & .671 \\
\hline $\begin{array}{l}\text { IBPP8 Real time customer support functionality } \\
\text { with a bank advisor through chat and SMS }\end{array}$ & $<---$ & InternalBusProcess & .836 \\
\hline IBPP9 Core Banking Solutions & $<---$ & InternalBusProcess & .888 \\
\hline LGP4 Learning climate in a branch. & $<---$ & LearningGrowthPrers & .849 \\
\hline LGP5 Stimulation of personal development & $<---$ & LearningGrowthPrers & .819 \\
\hline $\begin{array}{l}\text { LGP7 Sharing experience through video- } \\
\text { conferencing }\end{array}$ & $<---$ & LearningGrowthPrers & .692 \\
\hline $\begin{array}{l}\text { LGP8 Providing opportunity to work outside India. } \\
\text { (Timely Promotion) }\end{array}$ & $<---$ & LearningGrowthPrers & .700 \\
\hline $\begin{array}{l}\text { WCP6 Employees believe in working together } \\
\text { collaboratively, preferring cooperation over } \\
\text { competition. }\end{array}$ & $<---$ & WorkCulturePers & .846 \\
\hline $\begin{array}{l}\text { WCP7 Employees at all levels work together as a } \\
\text { tem to achieve results for the bank. }\end{array}$ & $<---$ & WorkCulturePers & .879 \\
\hline $\begin{array}{l}\text { WCP8 Employees believe that their concerns } \\
\text { during periods of change are heard and taken into } \\
\text { consideration. }\end{array}$ & $<---$ & WorkCulturePers & .844 \\
\hline $\begin{array}{l}\text { WCP9 Employees constantly stretch their goals, to } \\
\text { continuously improve. }\end{array}$ & $<---$ & WorkCulturePers & .768 \\
\hline FP2 NPA to net advances ratio. & $<---$ & FinancialPers. & .537 \\
\hline FP3 Return on equity. & <--- & FinancialPers. & .574 \\
\hline FP4 Capital adequacy ratio. & $<--$ & FinancialPers. & .564 \\
\hline FP7 Operating Profit by Average working funds & $<--$ & FinancialPers. & .763 \\
\hline $\begin{array}{l}\text { BPE1 It is a tool of motivation to achieve targets } \\
\text { for employees. }\end{array}$ & $<--$ & BankPerformance & .692 \\
\hline $\begin{array}{l}\text { BPE3 BSC can be linked to increments and other } \\
\text { financial benefits offered to employees. }\end{array}$ & $<---$ & BankPerformance & .705 \\
\hline $\begin{array}{l}\text { BPE2 Employees can be a part of strategy } \\
\text { implementation in true sense. }\end{array}$ & $<---$ & BankPerformance & .750 \\
\hline $\begin{array}{l}\text { WCP5 Employees participate in defining specific } \\
\text { goals. }\end{array}$ & $<--$ & WorkCulturePers & .611 \\
\hline
\end{tabular}


The constructs are also expected to covary. The estimation technique used in the model was Maximum Likelihood Estimation (MLE). The results of goodness of fit are exhibited in Table 2.

Table (b) exhibits the global goodness of fit indices of the measurement model proposed. The value of CMIN/df $=1.79$ was found to be highly satisfactory. Other leading goodness of fit statistics like CFI and IFI were highly satisfactory as their values were more than the minimum desired value of .95 . Badness of fit statistics i.e. RMSEA $=.044$ was also highly satisfactory as it was highly non-significant. Standardized RMR $=.0572$ was also very well acceptable as its value was below 0.08. Overall, the global goodness of fit statistics were highly acceptable suggesting fitness of the model. The misfit of data was minimum to the proposed model.

Table 2. Goodness of fit statistics of measurement model of balanced score card appraisal system comprising 7 constructs

\begin{tabular}{llll}
\hline Parameter & Estimated & Minimum Recommended & Remarks \\
\hline CMIN/df & 1.79 & Below 3 & Very good \\
\hline CFI & 0.955 & $>.95$ & Very good \\
\hline IFI & 0.955 & $>.95$ & Very good \\
\hline GFI & 0.900 & $>.95$ & Acceptable \\
\hline PGFI & 0.722 & & Acceptable \\
\hline TLI & 0.947 & $>.95$ & Very good \\
\hline RMSEA & 0.044 & $<.05$ & Very good \\
\hline Standardized RMR & 0.0572 & $<.05$ & Acceptable \\
\hline
\end{tabular}

\section{Assessment of Reliability and Validity of the Constructs}

\subsection{Construct Reliability}

To assess the reliability of the constructs, three most popular measures are (i) Composite reliability (CR); (ii) Average Variance Extracted (AVE); and $\operatorname{MaxR}(\mathrm{H})$. Composite reliability is the measure of reliability of measurement which is always considered to be better than Cronbach's alpha because it used the factor scores as weights to measure the participation of each measurement variable in estimation of a construct. The minimum recommended value of CR is .7. A construct should have value of CR greater than .7. As it can be seen from table(c) that except Accuracy all other constructs have CR >.7.

The second measure of reliability of model is Average Variance Extracted (AVE). The minimum recommended value of AVE is 0.5. As it can be seen that Financial Performance Perspective had AVE less than 0.5 suggesting poor variance explained. For remaining six constructs, the AVE was well above 0.5 suggesting sufficient variance of observed variables by their respective constructs.

The values of $\operatorname{MaxR}(\mathrm{H})$ were also higher than 0.9 suggesting the sufficient variance explained.

Table 3. Reliability statistics of measurement model

\begin{tabular}{llll}
\hline & CR & AVE & MaxR(H) \\
\hline Learning Growth Pers. & 0.851 & 0.590 & 0.867 \\
\hline Customer Orientation & 0.911 & 0.566 & 0.949 \\
\hline Service Orientation & 0.832 & 0.628 & 0.964 \\
\hline Internal Business Process & 0.844 & 0.646 & 0.971 \\
\hline Bank Performance & 0.759 & 0.513 & 0.974 \\
\hline Financial Performance Pers. & 0.705 & $\mathbf{0 . 3 8 0}$ & 0.976 \\
\hline Work Culture Pers. & 0.895 & 0.633 & 0.981 \\
\hline
\end{tabular}




\subsection{Construct Validity}

Construct validity is the extent to which a set of measured variables actually reflects the latent construct they are designed to measure (Hair et.al. 2010). Construct validity is established in by convergent validity and discriminant validity.

Convergent validity - The convergent validity refers to the degree to which the set of observed variables converge on to the construct they are meant to measure. Factor loadings and Average Variance Extracted (AVE) are two measure of convergent validity. From table(b), it may be seen that, in case of financial performance perspective construct, the factor loadings are below .6 but above .5 suggesting poor convergence of observed variables on their construct. All other factor loadings are well above .6 suggesting significant factor loadings or strong convergence of observed variables on to their respective constructs. Similarly, the AVE of financial performance was found to be below .5 suggesting poor convergent factor loading. All other constructs had AVE greater than .5 suggesting good convergent validity of constructs refer table (c).

Discriminant validity - Discriminant validity is a measure to describe how distinct two constructs are from each other. If discriminant validity of construct has been established, it suggested that the two constructs are truly different from each other. Discriminant validity can be assessed by comparing Square root of AVE with Inter-construct correlations. Square root of AVE should be higher than the inter-construct correlations. Table 4 exhibits the inter-construct correlations across off diagonals and square root of AVE on the diagonals. As it can be seen that the inter-construct correlation between bank performance and financial performance was very high suggesting high level of collenearity between two constructs. The financial performance and bank performance seems to be inseparable which seems to be problem in the model. All other constructs are discriminant or different from each other.

Table 4. Siminant validity statistics

\begin{tabular}{|c|c|c|c|c|c|c|c|}
\hline & $\begin{array}{l}\text { Learning } \\
\text { Growth } \\
\text { Pers. } \\
\end{array}$ & $\begin{array}{l}\text { Customer } \\
\text { Orientation }\end{array}$ & $\begin{array}{l}\text { Service } \\
\text { Orientation }\end{array}$ & $\begin{array}{l}\text { Internal } \\
\text { Business } \\
\text { Process } \\
\end{array}$ & $\begin{array}{l}\text { Bank } \\
\text { Performance }\end{array}$ & $\begin{array}{l}\text { Financial } \\
\text { Pers. }\end{array}$ & $\begin{array}{l}\text { Work } \\
\text { Culture } \\
\text { Pers. } \\
\end{array}$ \\
\hline $\begin{array}{l}\text { Learning } \\
\text { Growth } \\
\text { Pers. }\end{array}$ & 0.768 & & & & & & \\
\hline $\begin{array}{l}\text { Customer } \\
\text { Orientation } \\
\text { Pers. }\end{array}$ & 0.782 & 0.752 & & & & & \\
\hline $\begin{array}{l}\text { Service } \\
\text { Orientation } \\
\text { Pers. }\end{array}$ & 0.141 & 0.259 & 0.792 & & & & \\
\hline $\begin{array}{l}\text { Internal } \\
\text { Business } \\
\text { Process } \\
\end{array}$ & 0.254 & 0.282 & 0.370 & 0.804 & & & \\
\hline $\begin{array}{l}\text { Bank } \\
\text { Performance } \\
\text { Pers. }\end{array}$ & 0.219 & 0.180 & 0.193 & 0.260 & 0.716 & & \\
\hline $\begin{array}{l}\text { Financial } \\
\text { Performance } \\
\text { Pers. }\end{array}$ & 0.008 & 0.048 & 0.409 & 0.450 & 0.809 & 0.616 & \\
\hline $\begin{array}{l}\text { Work } \\
\text { Culture } \\
\text { Pers. } \\
\end{array}$ & 0.366 & 0.335 & 0.349 & 0.645 & 0.377 & 0.506 & 0.795 \\
\hline
\end{tabular}

\section{Findings}

- As banks' actual performance cannot be measured without analysing the financial ratios or perspectives so this perspective had highest effect among all predictors on banks' performance.

- In order to improve the banks performance in context of financial performance perspective, the banks have to focus firstly on return to equity and secondly on capital adequacy ratio. 
- If we consider the analysis of non-financial perspectives of Balanced Scorecard, Learning \& Growth perspective has been found the most important determinant of banks' performance as compared to other non-financial predictors of bank performance.

- While analysing the Learning \& Growth perspective, "Timely Promotion, Sharing experience through video-conferencing and stimulation of personal development" has been found the three more focused variables for improvement in employee skills.

- Under Customer Orientation perspective, "Banking network is accessible in all regions" has been found as the most important variable and "Number of redressal of customer complaint" has been considered as the second most important variable for improving the performance of banks.

- Under Service Orientation, "May I help you counter available" and "Senior citizens properly attended", variables should be focused more for improving the service quality perspective of banks.

- For increasing the Internal Business Process, it has been found that the two most important variables are "Core banking solutions" and "Real time customer support functionality with a bank advisor through chat and SMS" and banks have to focus more on these variables.

- It has been found that if banks willing to improve their Work Culture, they would need to focus on the improvement of four variables i.e. "Employees believe in working together collaboratively, preferring cooperation over competition", "Employees believe that their concerns during periods of change are heard and taken into consideration", "Employees at all levels work together as a tem to achieve results for the bank" and "Employees participate in defining specific goals" which will in turn lead to increase in their work culture perspective.

\section{Conclusion}

\subsection{In Terms of Financial Perspective}

- It is well aware that banking industry works in financial terms and profitability cannot be measured without taking into consideration the financial ratios.

- It has been found from the results generated by doing research that financial perspective is the most important variable in predicting the banks' performance or it can be concluded that financial ratios has highest effect among all predictors on banks' performance.

\subsection{In Terms of Non-financial Perspective}

- But the banking sector has expanded its focus area regarding performance analysis and started including other areas as well which has an impact on bank performance directly or indirectly.

- And while writing the conclusion, it is important to specify those areas which are not having much relevance in quantitative terms but qualitative significance has been increasing day by day.

\section{References}

Adewoye, J. O. (2013). Impact of Mobile Banking on Service Delivery in the Nigerian Commercial Banks. International Review of Management and Business Research, 2, 333-344.

Alex. (2014). The Impact of e-banking on Customer service and profitability of banks in Ghana. Global Journal of Commerce and Management Perspective, 3(1), 61-65.

Anand, M., Sahay, B. S., \& Saha, S. (2005, April-June). Balanced Scorecard in Indian Companies. Vikalpa, 30(2), 11-25. https://doi.org/10.1177/0256090920050202

Anyanwokoro. (1999). Impact of Electronic Banking Instruments on the intermediation efficiency of the Nigerian Economy. International Journal of Accounting Research, 1(6), 14-21.

Arthur, K., \& Yeung, B. B. (1997). Adding value through Human Resources: Reorienting Human Resource Measurement to drive Business Performance. Human Resource Management, 36(3), 321-335. https://doi.org/10.1002/(SICI)1099-050X(199723)36:3<321::AID-HRM4>3.0.CO;2-Y

Aspal, P. K., Dhawan, S., \& Nazneen, A. (2019). Significance of Bank Specific and Macroeconomic Determinants on Performance of Indian Private Sector Banks. International Journal of Economic and Financial Issues, 9(2), 168-174.

Chakraborty, P. K. (2007, April). Balanced Score Card - A Comprehensive Guide to Performance Evaluation. Banking and Finance Journal, 1625-1630. 
Collison, J., \& Frangos, C. (2002, Nobember). Aligning HR with Organization Strategy Survey. SHRM Research.

Davis, S., \& Albright, T. (2004). An Investigation of the Effect of Balanced Scorecard Implementation on Financial Performance. Management Accounting Research, 15(2), 135-153. https://doi.org/10.1016/j.mar.2003.11.001

Garrett Walker, J., \& Randall, M. (2001). Designing and Implementing an HR Scorecard. Human Resource Management, 40(4), 365-377. https://doi.org/10.1002/hrm.1025

Jalalpoor, M., Dolatabadi, H. R., \& Sanayei, A. (2011, October). An investigation in to Necessary Prerequisites for Implementation of Balanced Scorecard: Case Study: Ansar Bank. Interdisciplinary Journal of Contemporary Research in Business, 3(6), 383.

Janki, B. (2002). Unleashing Employee Productivity: Need for a paradigm shift. Indian Banking Association Bulletin, 24(3), 7-9.

Jham, V. I., \& Khan, K. M. (2008). Determinants of Performance in Retail Banking: Perspectives of Customer Satisfaction and Relationship Marketing. Singapore Management Review, 30, 35-45.

Kalaf, K. H., \& Al-Najjar, S. M. (2012, July). Designing a Balanced Scorecard to Measure a Bank's Performance: A Case Study. International Journal of Business Administration, 3(4), 44-53. https://doi.org/10.5430/ijba.v3n4p44

Komal, V. R. (2012, January). Progress of Banking in India: Customer's Perspectives. Business Intelligence Journal, $5(1)$.

Kristensen, K., \& Westlund, A. H. (2004, July-August). Performance Measurement and Business Results. Total Quality Management, 15(5-6), 719-733. https://doi.org/10.1080/14783360410001680206

Mittal, R. K., \& Dhingra, S. (2007). Assessing the Impact of Computerization on Productivity and Profitability of Indian Banks. Delhi Business Review, 8(1).

Munir, R., Perera, S., \& Baird, K. (2011). An Analytical Framework to Examine changes in Performance Measurement Systems within Banking Sector. Australasian Accounting Business and Finance Journal, 5(1), 93-115.

Phillips, P. A. (2007, September). The Balanced Scorecard and Strategic Control:A Hotel Case Study Analysis. The Service Industries Journal, 27(6), 731-746. https://doi.org/10.1080/02642060701453213

Rodgers, M. C., \& Keynes, M. (2011). Organizational critical success factors influencing balanced scorecard systems in UK healthcare. Journal of Management \& Marketing in Healthcare, 4(3), 174-179. https://doi.org/10.1179/1753304X11Y.0000000007

Simpson. (2002). The impact of the Internet in banking: Observations and evidence from developed and emerging markets. Telematics and Informatics, 19(4), 315-330. https://doi.org/10.1016/S0736-5853(01)00019-3

Solomon, C. M. (2000, March). Putting HR on the Scorecard. Workforce Optimas, 94-98.

Sureshchander, G. S., Rajendran, C., \& Anantharaman, R. N. (2003). Customer perceptions of Service Quality in the banking sector of a developing economy: a critical analysis. International Journal of Bank Marketing, 21(5), 233-242. https://doi.org/10.1108/02652320310488411

Zaribaf, M., \& Samandi, B. (2011). Balanced Scorecard and Determining the Relation of Strategic Goals and Performance Measures: Evidence, Semnan Province Tax Organizations of Iran). International Journal of General Management Studies, 2(2), 67-93. 